\title{
Plant residues, beneficial microbes and integrated phosphorus management for improving hybrid maize (Zea mays L.) growth and total biomass
}

\section{Amanullah;, Asif Iqbal, Asim Muhammad, Abdel Rahman Altawaha, Azizullah Shah and Brajendra Parmar}

Phosphorus $(P)$ unavailability and lack of organic matter in calcareous soils in semiarid climates are the major reasons for low crop productivity. This field experiment was conducted at the Agronomy Research Farm of The University of Agriculture Peshawar, during the summer of 2015 to investigate the impact of plant residues (PR) (faba bean, garlic and paper mulberry residues) and phosphorous sources [( 60 and $\left.120 \mathrm{~kg} \mathrm{ha}^{-1}\right)$ from single super phosphate (SSP) and poultry manure $(\mathrm{PM})]$ with $(+)$ and without $(-)$ phosphate solubilizing bacteria (PSB) on the phenological development, growth and biomass yield of hybrid maize "CS-200". Among the PR, application of faba bean residue was found to delay phenological development (days to tasseling, silking and physiological maturity), improved growth (taller plants, higher leaf area per plant and leaf area index) and produced the highest biomass yield (faba bean>garlic $>$ paper mulberry residues). Application of $P$ at the rate of $120 \mathrm{~kg} \mathrm{ha}^{-1}$ from the inorganic source (SSP) was more beneficial in terms of better growth and higher biomass yield (120-SSP $\geq 120-\mathrm{PM}>60-\mathrm{SSP}>60-\mathrm{PM} \mathrm{kg} \mathrm{P} \mathrm{ha-1).} \mathrm{The}$ plots with (+) PSB showed enhanced phenological development, produced significantly taller plants with higher leaf area per plant and leaf area index and produced the highest biomass yield. On the basis of these results we concluded that the application of faba bean residues, phosphorus at the rate of $120 \mathrm{kgha}^{-1}$ either from organic or inorganic sources with the inoculation of seed with PSB improved the growth and total biomass of hybrid maize in the study area.

Keywords: Zea mays L, Phenology, Growth, Biomass, Phosphate solubilizing bacteria, Plant Residues

'Address: Department of Agronomy, The University of Agriculture, Peshawar, Pakistan

*Corresponding Author. Address: Department of Agronomy, The University of Agriculture, Peshawar, Pakistan; Email: amanullah@aup.edu.pk 


\section{INTRODUCTION}

Maize (Zea mays L.) is the third most important cereal crop in Pakistan after wheat and rice. In Khyber Pakhtunkhwa it is ranked $2^{\text {nd }}$ after wheat in its importance (lqbal et al 2015). During 2012, maize was cultivated in Pakistan on an area of $1,087.3$ thousand hectares with a total production of $4,338.3$ thousand tons and a national average yield of $3,990 \mathrm{~kg} \mathrm{ha}^{-1}$. In Khyber Pakhtunkhwa, it was grown on 475.3 thousand hectares with a total production of 887.8 thousand tons and an average yield of $1,868 \mathrm{~kg} \mathrm{ha}^{-1}$ (MNFS and R, 2013-14).

Phosphorus $(P)$ is the most vital element in the nutrition of plants, next to nitrogen $(\mathrm{N})$. It plays a vital role in plant metabolism including photosynthesis, energy transfer, signal transduction, macromolecular biosynthesis, increased crop resistance to certain diseases and respiration (Khan et al 2010). Phosphorus increases the strength of cereal straw, stimulates root development, promotes flowering, fruit production and formation of seeds, and hastens the maturity of crops. Inorganic phosphorus occurs mostly in insoluble mineral complexes which cannot be absorbed by plants (Rengel and Marschner 2005). Soil organic matter is also a crucial reservoir of immobilized phosphorus that accounts for $20-80 \%$ of phosphorus in soils. Due to its fixation into an unavailable form, out of the total phosphorus that exists in soil only $0.1 \%$ is available for plant uptake. Therefore more chemical fertilizers have been used to restock soil nutrients which has resulted in high costs and unadorned environmental contamination.

The crop residues help to recycle nutrients (Akhtar et al 2015). Organic material inputs mainly include organic fertilizers, plant residues, and other organic debris. Crop residues are good sources of plant nutrients and are important components for the stability of agricultural ecosystems ( Li et al 2015). Studies have revealed that the use of organic materials improves the nitrogen to phosphorous $(N: P)$ ratio and the yield. Due to high fertilizer costs, decline of soil health and environmental concerns, organic manures have become more indispensable. Plant residues on decomposition produce organic phosphorous with the help of soil microorganism (Richardson and Simpson 2011). Vegetable and flower residues which are rich in nitrogen, phosphorous and potassium can be used as fertilizer, which is more appropriate for waste management (Weaterman and Bicudo 2014, Han and $\mathrm{He}$ 2010).

Stefan (2003) specified that fresh poultry droppings contain $1.1 \% \mathrm{P}_{2} \mathrm{O}_{5}$, while dried poultry manure contains $3.5 \% \quad \mathrm{P}_{2} \mathrm{O}_{5}$. Among organic manures, the incorporation of poultry manure can improve the growth and production of maize (Tambone et al 2007). Poultry manure is the richest known farmyard manure supplying plant nutrients. Amujoyegbe et al (2007) observed that poultry droppings caused the increase in leaf area, total chlorophyll content and dry matter as well as the grain yield of maize and sorghum. Poultry manure decomposes more rapidly than other animal manures and comprises the essential nutrients ie. Nitrogen, phosphorus and potassium necessary for enhancing the growth and yield of crops.

Bio-fertilizers hasten and improve plant growth and protect plants from pests and diseases (El-yazeid et al 2007). Phosphate solubilizing bacteria (PSB) have been reported to be active in the conversion of insoluble phosphate to soluble orthophosphate ions (Chabot et al 1993). PSB is eco-friendly, effective and a reasonable substitute for chemical fertilizers (Hafeez et al 2002). Soil microorganisms also play a vital role in providing and recycling nutrients for plant 
growth, boosting crop production and improving soil quality (Wu et al 2005). Microbial inoculants are now being explored worldwide for their potential to mobilize unavailable phosphorous, thereby increasing its availability for uptake by plants. Phosphate solubilizing microorganisms could enhance its solubility by releasing bound organic phosphates through intensifying the rate of hydrolytic cleavage.

Phosphorus and organic matter are the major limiting factors for crop production in Khyber Pakhtunkhwa-Pakistan. The application of plant residues (PR), phosphorous sources (PS) and phosphate solubilizing bacteria (PSB) could increase phosphorous availability and crop productivity. There is no research to investigate the interactive effects of PRxPSxPSB in Khyber Pakhtunkhwa. This research was therefore designed to study the interactive effects of PRxPSxPSB on growth and biomass yield of hybrid maize.

\section{MATERIALS AND METHODS}

Field experiments were conducted to investigate the impact of plant residues from faba beans, garlic and paper mulberry, each residue was applied separately at the rate of $10 \mathrm{t} \mathrm{ha}^{-1}$; two phosphorus $(P)$ levels [low $\left(60 \mathrm{~kg} \mathrm{ha}^{-1}\right)$ and high $\left.\left(120 \mathrm{~kg} \mathrm{ha}^{-1}\right)\right]$ from two sources viz. inorganic source SSP (single super phosphate) and organic source (poultry manure); and two PSB (phosphate solubilizing bacteria) treatments [inoculated seeds with PSB (+) and seeds not inoculated with PSB (-)]. The effect of these treatments on phenology, growth and biomass yield of hybrid (CS 200) maize (Zea mays L.) was measured. This research was conducted during the summer season of 2015 at the Agronomy Research Farm of The University of Agriculture Peshawar. This area has a semiarid climate.

\section{Experimental Design}

The experiment was laid out in a randomized complete block design with a split plot arrangement, using three replications. Plant residues and phosphorus sources were used as the main plot factor. Phosphate solubilizing bacteria (with and without PSB) was applied to the sub plot. One control plot (with no plant residues, no phosphorus sources and no PSB applied) was used per replication for comparison with the average of the treated (fertilized) plots. Each subplot consisted of five rows, $3 \mathrm{~m}$ long and $70 \mathrm{~cm}$ apart. The hybrid corn seeds were sown at the rate of $30 \mathrm{~kg}$ $\mathrm{ha}^{-1}$ and after emergence a uniform plant density of 70,000 plants per ha was maintained in each plot. The required organic sources were applied about one month before sowing, while the inorganic $P$ source (SSP) was applied at seedbed preparation one day before sowing. The inoculated seeds (+PSB) and un-inoculated seeds (-PSB) were sown in their respective plots in rows $70 \mathrm{~cm}$ apart. A uniform dose of nitrogen $150 \mathrm{~kg} \mathrm{ha}^{-1}$ urea was applied in two equal splits, that is, half at sowing, and half when plants attained knee height.

\section{PSB Application Method}

The PSB was obtained from the National Agricultural Research Center (NARC), Islamabad. The PSB contains bacteria (Pseudomonas striata), carrier mixture (pine 
powder of partical size $10-40 \mu \mathrm{m}$ ) and adhesive materials was added which helps the PSB to stick on the seed surface. One pack of PSB contains $1 \times 10^{8}$ bacterial cells per $\mathrm{kg}$. PSB was applied by seed inoculation at the rate of $200 \mathrm{~g}$ per $10 \mathrm{~kg}$ of maize seeds. Maize seeds were moisten thoroughly with water and then the PSB slurry was added to the seeds. The inoculated seeds were kept for $10-15 \mathrm{~min}$ in the shade before sowing.

\section{Data Recording}

The number of days to tasseling for each subplot was calculated and recorded from the date of sowing to the date when $75 \%$ tasseling appeared. The days to silking, when $75 \%$ silking had emerged in each subplot were also noted. Days to physiological maturity were recorded for each subplot from the date of sowing until all the plants reached physiological maturity. Data on plant height $(\mathrm{cm})$ at physiological maturity was recorded using a meter rod by selecting ten plants randomly from each subplot and the results averaged. For calculating the leaf area, leaf length and leaf width of five randomly selected plants in each subplot were measured. Leaf width was measured near the stem, in the middle of the leaf and near the tip, then the average of these three values was calculated for the leaf width. The leaf area was calculated by using the following formula:

$$
\begin{aligned}
\text { Leaf area }\left(\mathrm{cm}^{2}\right) & =\text { Leaf length } \mathrm{x} \text { Leaf width } \mathrm{x} \text { factor } \\
\text { Factor } & =0.75(\text { Amanullah et al } 2009)
\end{aligned}
$$

Leaf area index was calculated as leaf area per plant divided by ground area per plant.

To record data on biomass yield, three central rows were harvested in each subplot. The material was sundried and weighed by spring balance and then converted into $\mathrm{kg} \mathrm{ha}^{-1}$ by the following formula.

$$
\text { Total Dry-Biomass yield }\left(\mathrm{kg} \mathrm{ha}^{-1}\right)=\frac{\text { Biomass yield }(\mathrm{kg}) \text { in three central rows }}{\text { No. of rows } x \text { Row length } x \mathrm{R}-\mathrm{R} \text { distance }} 10000\left(\mathrm{~m}^{2}\right)
$$

\section{Statistical Analysis}

Data were statistically analyzed according to Steel et al (1996) and means were compared using LSD test $(p \leq 0.05)$. The detailed analysis of variance and significance levels regarding all the parameters studied are given in Tables 1 and 3 . For the statistical analysis MS-Excel was used.

\section{RESULTS}

\section{Plant Height}

Plant height $(\mathrm{cm})$ statistical analysis data are presented in (Table 1). Faba bean residues resulted in taller plants $(219.4 \mathrm{~cm})$ as compared to garlic residues and paper mulberry residues $(217.3 \mathrm{~cm}$ and $215.7 \mathrm{~cm}$, respectively) as shown in Table 2. Application of a higher $P$ rate $\left(120 \mathrm{~kg} \mathrm{ha}^{-1}\right)$ either from an inorganic source (SSP) or 
organic source (poultry manure) increased plant height $(226.3 \mathrm{~cm}$ and $220.4 \mathrm{~cm}$, respectively). The plots sown with PSB inoculated seeds of maize produced taller plants $(219.4 \mathrm{~cm})$ than plots without PSB inoculation $(215.5 \mathrm{~cm})$. Planned mean comparisons data revealed that short stature plants were recorded in the control plot $(203.5 \mathrm{~cm})$ while treated plots measured $(217.5 \mathrm{~cm})$.

Table 1. Analysis of variance for days from sowing to tasseling, silking, physiological maturity and plant height $(\mathrm{cm})$ of hybrid maize as affected plant residues and phosphorus sources with and without phosphate solubilizing bacteria

\begin{tabular}{|c|c|c|c|c|c|}
\hline Source of variance & $\begin{array}{l}\text { Degree } \\
\text { of } \\
\text { freedom }\end{array}$ & $\begin{array}{c}\text { Days } \\
\text { to } \\
\text { tasseling }\end{array}$ & $\begin{array}{l}\text { Days } \\
\text { to } \\
\text { silking }\end{array}$ & $\begin{array}{c}\text { Days } \\
\text { to physiological } \\
\text { maturity }\end{array}$ & $\begin{array}{l}\text { Plant } \\
\text { height } \\
\text { (cm) }\end{array}$ \\
\hline Rep. & 2 & ns & ns & ns & ns \\
\hline Treat. (T) & [12] & $\star \star$ & $\star \star \star \star ~$ & 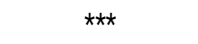 & $\star \star \star ~$ \\
\hline Crop residue(CR) & $\{2\}$ & * & ** & 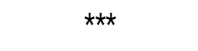 & $\star \star \star$ \\
\hline P management (PM) & $\{3\}$ & $\star \star \star$ & 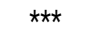 & $\star \star \star ~$ & $\star \star \star ~$ \\
\hline CR $\times$ PM & $\{6\}$ & ns & ns & ns & ns \\
\hline Control vs. rest & $\{1\}$ & ** & $\star \star \star ~$ & $\star \star \star$ & $\star \star \star ~$ \\
\hline Error 1 & 24 & & & & \\
\hline Phosphate solubilizing bacteria (PSB) & 1 & * & ns & * & $\star \star \star \star$ \\
\hline PSB $\times T$ & [12] & ns & ns & ns & ns \\
\hline PSB $\times C R$ & $\{2\}$ & ns & ns & ns & ns \\
\hline PSB $\times$ PM & $\{3\}$ & ns & * & ns & ns \\
\hline PSB $\times$ CR $\times$ PM & $\{6\}$ & ns & ns & ns & ns \\
\hline PSB $x$ Control vs. rest & $\{1\}$ & ns & ns & ns & ns \\
\hline Error 2 & 26 & & & & \\
\hline Total & 77 & & & & \\
\hline CV-I (\%) & & 2.6 & 2.15 & 1.21 & 1.21 \\
\hline CV-II (\%) & & 1.9 & 1.36 & 1.45 & 0.77 \\
\hline
\end{tabular}

$(*, * \star, * \star *)$ indicates that data is significant at 5,1 and $0.1 \%$ level of probability, respectively. The word ns stand for the non-significant data at $5 \%$ level of probability.

\section{Days to Tasseling, Silking and Physiological Maturity}

Faba bean residues delayed tasseling (57 days) as compared to paper mulberry residues (56 days each) (Tables 1 and 2 ). Application of a higher $P$ rate $\left(120 \mathrm{~kg} \mathrm{ha}^{-1}\right)$ either from an inorganic source (SSP) or organic source (poultry manure) produced early tasseling ( 55 and 56 days, respectively). The plots sown with PSB inoculated seeds took fewer days to tasseling (56 days) than plots without PSB inoculation (57 days). The other treated plots had fewer days to tasseling (57) than the control (59 days).

Faba bean residues delayed silking (64 days) as compared to paper mulberry residues and garlic residues (62 days each). Application of a higher $P$ rate $(120 \mathrm{~kg}$ $\mathrm{ha}^{-1}$ ) from each source took fewer days to silking (61 and 62 days, respectively). The plots sown with PSB inoculated seeds of maize took fewer days to silking (63 days) than plots without PSB inoculation (64 days). The other treated plots had 63 days to silking compared to the control which took (66 days). Inoculation of maize seeds 
with PSB along with the higher $\mathrm{P}$ rate either from an organic or inorganic source reduced days to silking (PSBXPS) as shown in figure 1.

Table 2. Days from sowing to tasseling, silking, physiological maturity and plant height $(\mathrm{cm})$ of hybrid maize as affected by plant residues and phosphorus sources with and without phosphate solubilizing bacteria

\begin{tabular}{|c|c|c|c|c|}
\hline Plant residue (PR) & $\begin{array}{l}\text { Days } \\
\text { to tasseling }\end{array}$ & $\begin{array}{l}\text { Days } \\
\text { to silking }\end{array}$ & $\begin{array}{c}\text { Days } \\
\text { to physiological maturity }\end{array}$ & $\begin{array}{l}\text { Plant height } \\
\text { (cm) }\end{array}$ \\
\hline Paper mulberry & $56 \mathrm{~b}$ & $62 \mathrm{~b}$ & $99 \mathrm{~b}$ & $215.7 c$ \\
\hline Garlic & $56 b$ & $62 b$ & $99 \mathrm{~b}$ & $217.3 b$ \\
\hline Faba bean & $57 a$ & $64 a$ & $100 a$ & $219.4 a$ \\
\hline LSD & 0.9 & 0.8 & 0.7 & 1.6 \\
\hline \multicolumn{5}{|l|}{ P-Sources $\left(\mathrm{kg} \mathrm{ha}^{-1}\right)$} \\
\hline $60-S S P$ & $57 a b$ & $63 \mathrm{~b}$ & $100 \mathrm{~b}$ & $213.5 \mathrm{c}$ \\
\hline 120-SSP & $55 \mathrm{c}$ & $61 d$ & $98 d$ & $226.3 a$ \\
\hline 60-PM & $58 a$ & $64 a$ & $101 a$ & $209.6 d$ \\
\hline 120-PM & $56 \mathrm{bc}$ & $62 c$ & $99 \mathrm{c}$ & $220.4 b$ \\
\hline LSD & 1 & 0.9 & 0.8 & 1.8 \\
\hline \multicolumn{5}{|l|}{ PSB } \\
\hline With PSB & $56 \mathrm{~b}$ & $63 b$ & $99 \mathrm{~b}$ & $219.4 a$ \\
\hline Without PSB & $57 a$ & $64 a$ & $100 \mathrm{a}$ & $215.5 b$ \\
\hline LSD & 1 & 0.4 & 0.7 & 0.8 \\
\hline Control & $59 a$ & $66 a$ & $103 a$ & $203.5 b$ \\
\hline Rest & $57 b$ & $63 b$ & $99 b$ & $217.5 a$ \\
\hline \multicolumn{5}{|l|}{ Interactions } \\
\hline$P R \times P S$ & ns & ns & ns & ns \\
\hline PSB $\times P R$ & ns & ns & ns & ns \\
\hline PSB $\times$ PS & ns & * & ns & ns \\
\hline PSB $\times$ PR $\times$ PS & ns & ns & ns & ns \\
\hline
\end{tabular}

Means of the same category followed by different letters are significantly different from each other using LSD test ( $p \leq 0.05)$. Where: ns stands for non-significant data using LSD test $(p \leq 0.05)$.

Application of Faba bean residues delayed physiological maturity (100 days) as compared to paper mulberry residues and garlic residues (99 days each). Application of the higher $P$ rate $\left(120 \mathrm{~kg} \mathrm{ha}^{-1}\right)$ either from an inorganic source (SSP) or organic source (poultry manure) reduced the days to physiological maturity ( 98 and 99 days, respectively). The plots sown with PSB inoculated seeds took fewer days to physiological maturity (99 days) than plots without PSB inoculation (100 days). The rest of the treated plots had fewer days to physiological maturity ( 99 days) than the control (103 days).

\section{Leaf Area per Plant and Leaf Area Index}

The leaf area $\left(\mathrm{cm}^{2}\right)$ of the maize hybrid is presented in Tables 3 and 4 . Application of Faba bean residues resulted in a larger leaf area per plant $\left(6,099 \mathrm{~cm}^{2}\right)$ as compared to garlic residues and paper mulberry residues $\left(5,878 \mathrm{~cm}^{2}\right.$ and $5,758 \mathrm{~cm}^{2}$, respectively). Application of higher $P$ rate $\left(120 \mathrm{~kg} \mathrm{ha}^{-1}\right)$ either from inorganic sources (SSP) or organic source (poultry manure) improved LA $\left(6,361 \mathrm{~cm}^{2}\right.$ and $6,041 \mathrm{~cm}^{2}$ ) of hybrid maize. The plots sown with PSB inoculated seeds 
produced a higher LA $\left(6,072 \mathrm{~cm}^{2}\right)$ than plots without PSB inoculation $\left(5,752 \mathrm{~cm}^{2}\right)$. Planned mean comparisons data revealed that a lower $L A$ per plant was recorded in the control plot $\left(4,845 \mathrm{~cm}^{2}\right)$ than in treated plots $\left(5,912 \mathrm{~cm}^{2}\right)$. Inoculation of maize seeds with PSB along with the higher $P$ rate either from organic or inorganic sources increased the leaf area per plant of hybrid maize (PSBxPS) as presented in figure 2. Data on leaf area index ( $\mathrm{LAl}$ ) are also shown in tables 3 and 4. PR, PS, PSB and control (no residues, $\mathrm{P}$ and PSB applied) vs. rest (average of all treated plots) and PSBxPS interaction had significant effects on LAI. Faba bean residues had the highest LAI (4.3) as compared to garlic residues and paper mulberry residues with 4.1 and 4.0 each, respectively. Application of the higher $P$ rate $\left(120 \mathrm{~kg} \mathrm{ha}^{-1}\right)$ either from inorganic sources (SSP) or organic source (poultry manure) enhanced the LAI (4.5 and 4.2, respectively). The plots sown with PSB inoculated seeds produced higher LAI (4.3) than plots without PSB inoculation (4.0). Planned mean comparisons data revealed that the lowest LAI was recorded in the control plot (3.4) compared to treated plots (4.1). Figure 3 shows inoculation of maize seeds with $P S B$ along with the higher $P$ rate either from an organic or inorganic source increased the LAl of hybrid maize (PSBXPS).

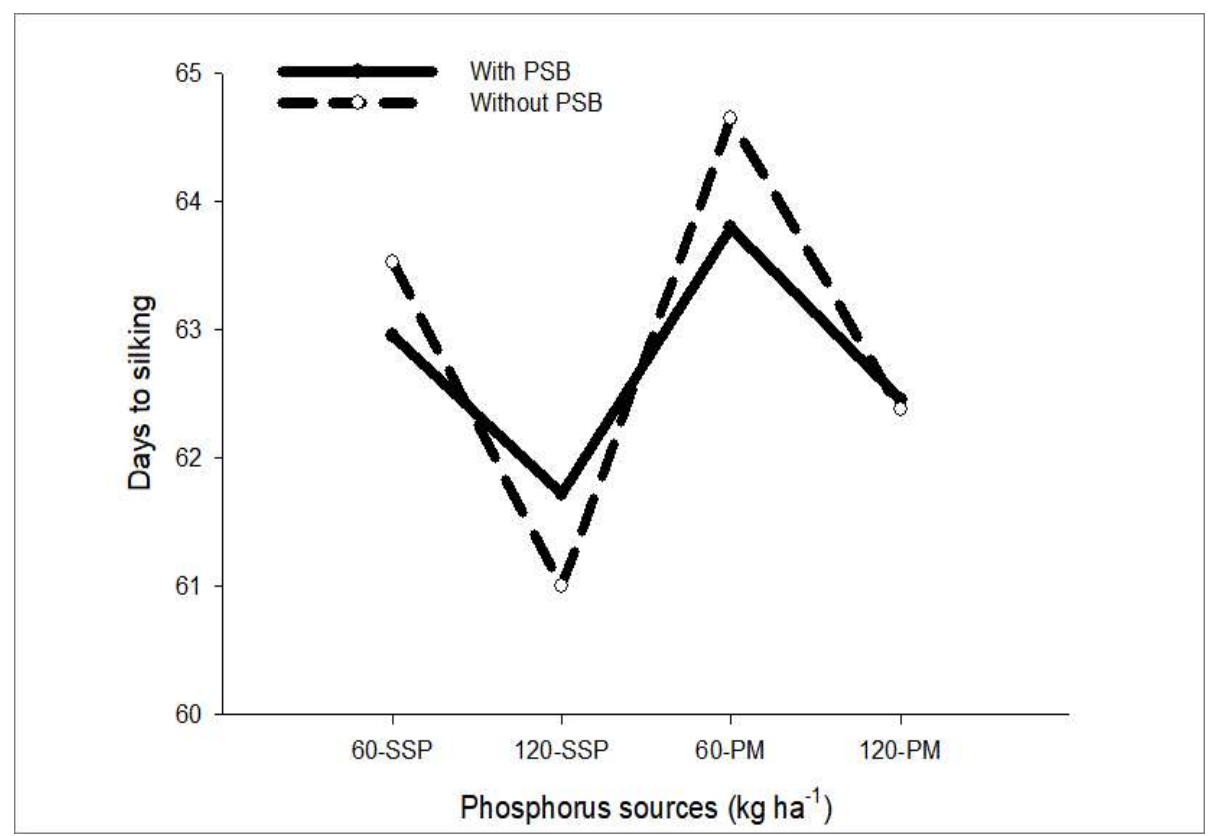

Figure 1. Response of days to silking of maize hybrid to phosphorus sources with and without phosphate solubilizing bacteria (PSxPSB) 


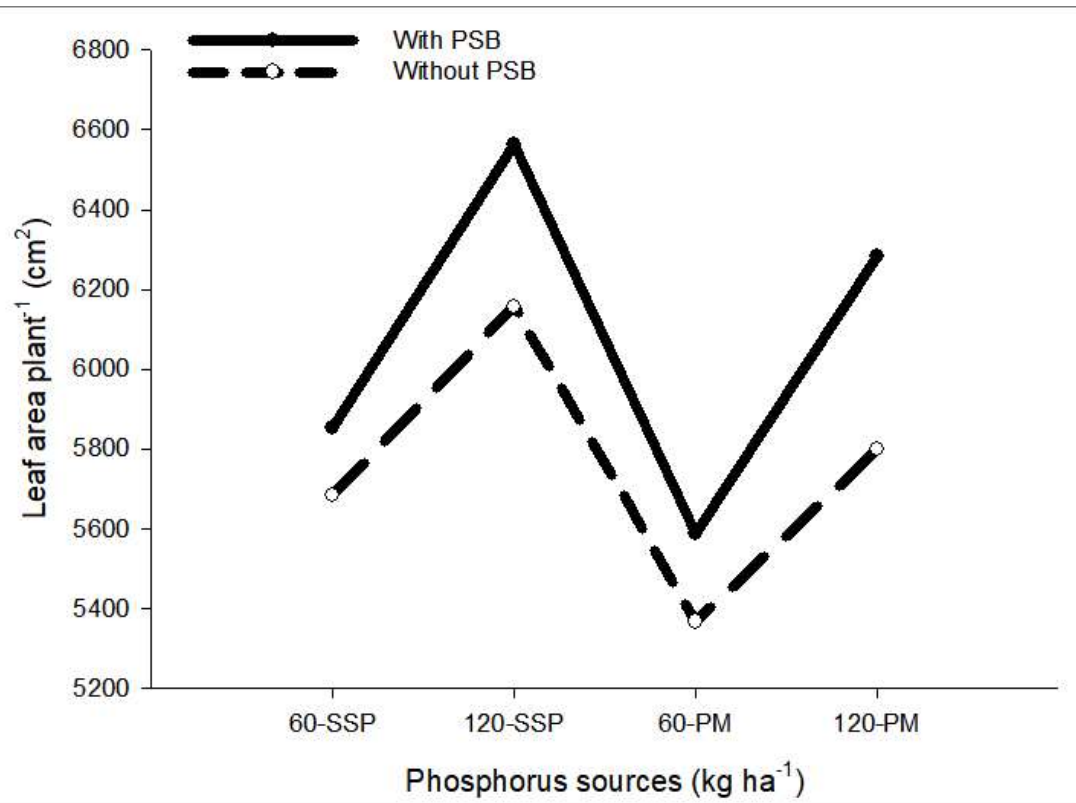

Figure 2. Response of leaf area plant ${ }^{1}\left(\mathrm{~cm}^{2}\right)$ of maize hybrid to phosphorus sources with and without phosphate solubilizing bacteria (PSxPSB).

Table 3. Analysis of variance for leaf area plant ${ }^{-1}\left(\mathrm{~cm}^{2}\right)$, leaf area index and biomass yield $\left(\mathrm{kg} \mathrm{ha}^{-1}\right)$ of hybrid maize as affected by plant residues and phosphorus sources with and without phosphate solubilizing bacteria

\begin{tabular}{|c|c|c|c|c|}
\hline Source of Variance & $\begin{array}{l}\text { Degree of } \\
\text { freedom }\end{array}$ & $\begin{array}{l}\text { Leaf area } \\
\text { plant }^{-1}\left(\mathrm{~cm}^{2}\right)\end{array}$ & $\begin{array}{l}\text { Leaf area } \\
\text { Index }\end{array}$ & $\begin{array}{c}\text { Biomass yield } \\
\quad\left(\mathrm{kg} \mathrm{ha}^{-1}\right)\end{array}$ \\
\hline Rep. & 2 & NS & NS & NS \\
\hline Treat. (T) & [12] & $\star \star \star \star ~$ & $\star \star \star \star ~$ & 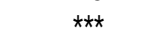 \\
\hline Crop residue (CR) & $\{2\}$ & 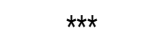 & 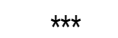 & ** \\
\hline$P$ management (PM) & $\{3\}$ & 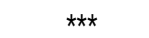 & 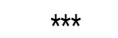 & 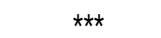 \\
\hline CR $\times P M$ & $\{6\}$ & NS & NS & * \\
\hline Control vs. Rest & $\{1\}$ & $\star \star \star \star ~$ & $\star \star \star *$ & $\star \star \star \star ~$ \\
\hline Error 1 & 24 & & & \\
\hline PSB & 1 & $\star \star \star$ & $\star \star \star$ & $\star \star \star$ \\
\hline PSB $\times T$ & [12] & NS & NS & NS \\
\hline$P S B \times C R$ & $\{2\}$ & NS & NS & NS \\
\hline BF xPM & $\{3\}$ & * & * & * \\
\hline$B F \times C R \times P M$ & $\{6\}$ & NS & NS & NS \\
\hline BF $x$ Control vs. Rest & $\{1\}$ & NS & NS & NS \\
\hline Error 2 & 26 & & & \\
\hline Total & 77 & & & \\
\hline CV-I (\%) & & 4.18 & 4.18 & 2.05 \\
\hline CV-II (\%) & & 3.01 & 3.01 & 2.94 \\
\hline
\end{tabular}

$(\star, \star \star, \star \star \star)$ indicates that data is significant at 5,1 and $0.1 \%$ level of probability, respectively. The word ns stand for the non-significant data at $5 \%$ level of probability. 
Table 4. Leaf area plant ${ }^{-1}\left(\mathrm{~cm}^{2}\right)$, leaf area index and biomass yield $\left(\mathrm{kg} \mathrm{ha}^{-1}\right)$ of hybrid maize as affected by plant residues and phosphorus sources with and without phosphate solubilizing bacteria.

\begin{tabular}{lccc}
\hline Plant residue (PR) & Leaf area plant ${ }^{-1}\left(\mathrm{~cm}^{2}\right)$ & Leaf area index & Biomass yield $\left(\mathrm{kg} \mathrm{ha}^{-1}\right)$ \\
\hline Paper mulberry & $5758 \mathrm{~b}$ & $4.0 \mathrm{~b}$ & $14410 \mathrm{~b}$ \\
Garlic & $5878 \mathrm{~b}$ & $4.1 \mathrm{~b}$ & $14541 \mathrm{~b}$ \\
Faba bean & $6099 \mathrm{a}$ & $4.3 \mathrm{a}$ & $14731 \mathrm{a}$ \\
\hline LSD & 145 & 0.1 & 176 \\
\hline P-Sources $\left(\mathrm{kg} \mathrm{ha}^{-1}\right)$ & & & \\
$60-$ SSP & $5768 \mathrm{c}$ & $4.0 \mathrm{c}$ & $14320 \mathrm{c}$ \\
120-SSP & $6361 \mathrm{a}$ & $4.5 \mathrm{a}$ & $15363 \mathrm{a}$ \\
$60-\mathrm{PM}$ & $5478 \mathrm{~d}$ & $3.8 \mathrm{~d}$ & $13661 \mathrm{~d}$ \\
120-PM & $6041 \mathrm{~b}$ & $4.2 \mathrm{~b}$ & $14900 \mathrm{~b}$ \\
\hline LSD & 168 & 0.12 & 203 \\
\hline PSB & & & \\
With PSB & $6072 \mathrm{a}$ & $4.3 \mathrm{a}$ & $14917 \mathrm{a}$ \\
Without PSB & $5752 \mathrm{~b}$ & $4.0 \mathrm{~b}$ & $14205 \mathrm{~b}$ \\
\hline LSD & 85 & 0.06 & 205 \\
\hline Control & $4845 \mathrm{~b}$ & $3.4 \mathrm{~b}$ & $12695 \mathrm{~b}$ \\
Rest & $5912 \mathrm{a}$ & $4.1 \mathrm{a}$ & $14561 \mathrm{a}$ \\
\hline Interactions & & & \\
PR x PS & $\mathrm{ns}$ & $\mathrm{ns}$ & ns \\
PSB x PR & $\mathrm{ns}$ & $\mathrm{ns}$ & * \\
PSB x PS & $*$ & $\mathrm{~ns}$ & $\mathrm{~ns}$ \\
PSB x PR x PS & $\mathrm{ns}$ & & \\
\hline
\end{tabular}

Means of the same category followed by different letters are significantly different from each other using LSD test ( $p \leq 0.05)$. Where: ns stands for non-significant data using LSD test ( $p \leq 0.05)$.

\section{Total Dry-BiomassYield}

Incorporation of faba bean residues resulted in greater total dry-biomass yield $\left(14,731 \mathrm{~kg} \mathrm{ha}^{-1}\right)$ as compared to paper mulberry residues $\left(14,410 \mathrm{~kg} \mathrm{ha}^{-1}\right)$ as shown in Tables 3 and 4 . Application of a higher $P$ rate $\left(120 \mathrm{~kg} \mathrm{ha}^{-1}\right)$ either from an inorganic source or organic source improved total dry-biomass yields $(15,363$ and $14,900 \mathrm{~kg}$ $\mathrm{ha}^{-1}$, respectively). Inoculation of seeds with PSB produced more dry-biomass yield $\left(14,917 \mathrm{~kg} \mathrm{ha}^{-1}\right)$ than plots without PSB inoculation $\left(14,205 \mathrm{~kg} \mathrm{ha}^{-1}\right)$. Planned mean comparisons data showed that the treated plots (rest) produced a higher drybiomass yield $\left(14,561 \mathrm{~kg} \mathrm{ha}^{-1}\right)$ than the control plot $\left(12,695 \mathrm{~kg} \mathrm{ha}^{-1}\right)$. Application of any plant residue along with the higher $P$ rate either from an organic or inorganic source increased total dry-biomass yield kgha-1 (PRxPS) as shown in figure 4 . In the case of (PSBxPR) inoculation of maize seeds with PSB along with any plant residues increased total dry-biomass yield kgha $^{-1}$ of hybrid maize (Figure 5). 


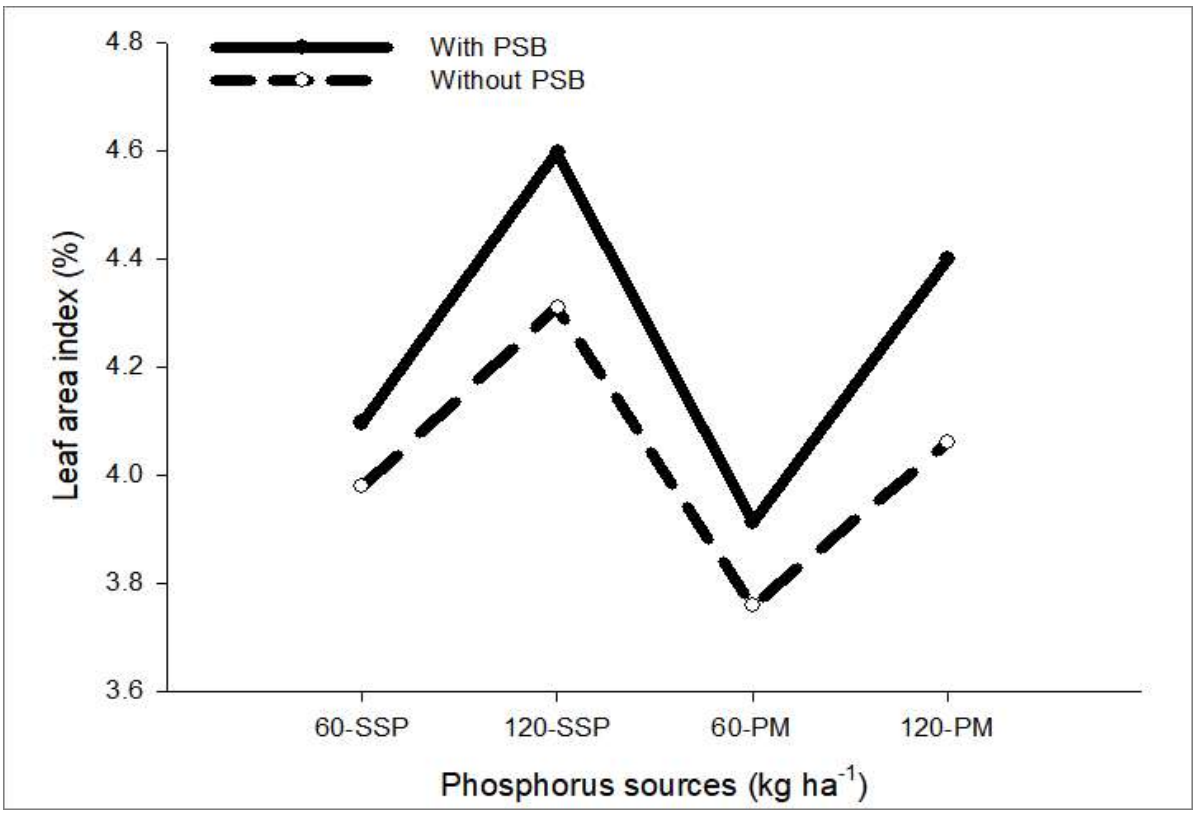

Figure 3. Response of leaf area index of maize hybrid to phosphorus sources with and without phosphate solubilizing bacteria (PSxPSB).

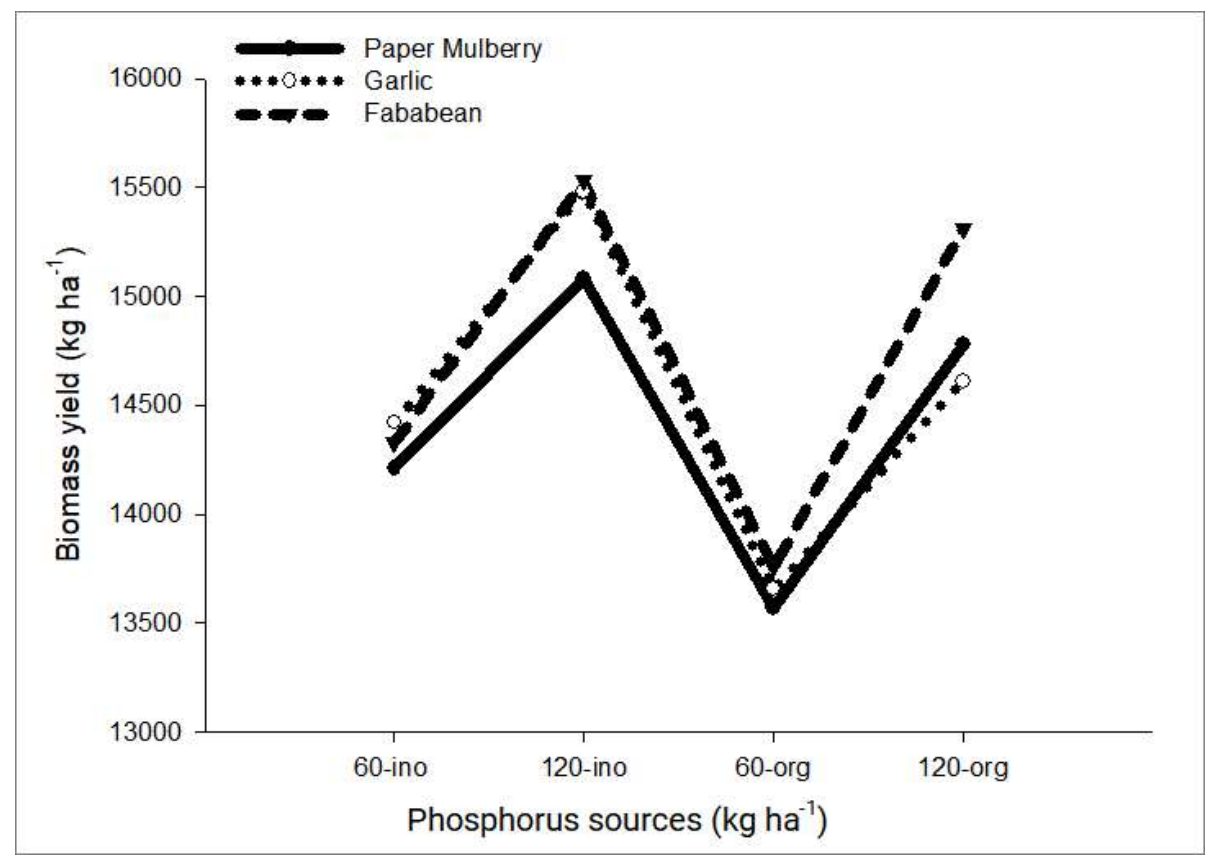

Figure 4. Response of biomass yield $\left(\mathrm{kg} \mathrm{ha}^{-1}\right)$ of maize hybrid to phosphorus sources and plant residues (PSXPR). 


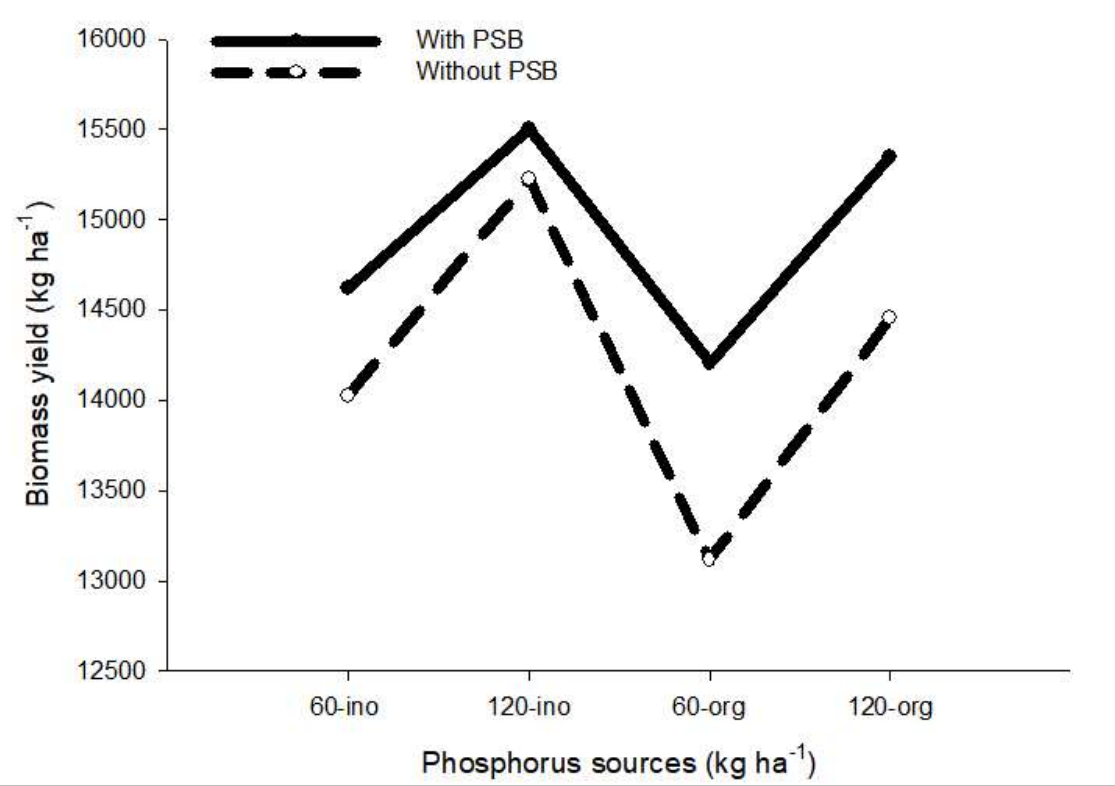

Figure 5. Response of biomass yield $\left(\mathrm{kg} \mathrm{ha}^{-1}\right)$ of maize hybrid to phosphorus sources with and without phosphate solubilizing bacteria (PSxPSB).

\section{DISCUSSION}

Phenological development is important for the determination of crop maturity and regulating the partitioning of dry matter among various parts of the crop. Our results indicated that PR significantly affected days to tasseling, silking and physiological maturity of maize. Phenological development (tasseling, silking and maturity) was delayed with the application of faba bean residues, whereas earlier phenological development was observed with the application of garlic and paper mulberry residues. Incorporated legume residues decompose readily and improve soil fertility which prolongs the life cycle of the residue-incorporated plots compared to control plots (Evans and Armstrong 1991). Akhtar et al (2015) noted that incorporation of mung bean residue delayed phenological development.

Maize phenology (tasseling, silking and physiological maturity) was enhanced with the higher $\mathrm{P}$ application $\left(120 \mathrm{~kg} \mathrm{ha}^{-1}\right)$ than the lower rate $\left(60 \mathrm{~kg} \mathrm{ha}^{-1}\right)$ either from SSP or PM. The reason for the early phenology with the application of higher P levels might be due to better root development which facilitated the plants to obtain more $P$ and other nutrients from the poultry manure resulting in rapid plant growth and development (Amanullah and Khalid 2015). These findings are in line with those of Mahmood et al (2001) who reported early phenological parameters with high levels of $P$ in maize crops. According to Amanullah et al (2010) the early phenological development in maize with $P$ application may be due to the increased root development which helps the plants to obtain more $\mathrm{P}$ to complete its life cycle quickly. Rapid plant growth and development in maize with the highest rate of $P$ was also reported by Singaram and Kothandaraman (1994). On the other hand, early phenological development in maize with $\mathrm{P}$ application might be due to the efficient 
utilization of $P$ by maize plants (Griffith 1983). Amanullah et al (2016) and Amanullah and Khalid (2015) reported that the highest $P$ level enhanced maturity/phenology in maize plants as compared to lower $\mathrm{P}$ levels and the control. Higher addition of phosphorous enhanced phenological development as well as the growth period in wheat crops (Khan et al 2008, Hussain et al 2008).

Phenological development in our study was also enhanced with the application of PSB as compared to plants without PSB. The reason for early maturity in phenology with PSB might be due to the mineralization of bound $\mathrm{P}$ (organic phosphate) to mineral $\mathrm{P}$ (inorganic phosphate) that lowers the $\mathrm{pH}$ of the medium due to the release of organic acids (Maliha et al 2004, Whitelaw 2000). According to Vyas and Gulati (2009), PSB improved soil fertility by releasing bound P and therefore improved crop growth and increased crop productivity. Nezarat and Gholami (2009) reported that plant growth promoting rhizobacteria have a positive impact on maize growth and development.

Plant stature affects crops in several ways and had a direct and positive effect on biomass yield. The height of the crop is mainly controlled by the genetic makeup of the genotype and it can also be affected by the environmental factors (Shahzad et al 2007). Growth parameters (plant height, leaf area per plant and LAI) were significantly improved with the application of faba bean residues over garlic and paper mulberry residues. Decomposition of faba bean residues is more rapid than garlic and paper mulberry residues which releases more nutrients to the crop and improves soil health. Residue incorporation increased the mineral $\mathrm{N}$ content of the soil by $22.40 \%$ according to Kumar and Goh (2002). Incorporation of residues produced taller plants compared to no incorporation (Akhtar et al 2015 and Silva et al 2006).

Taller plants were produced with the application of $120 \mathrm{~kg} \mathrm{P} \mathrm{ha}^{-1}$ than with $60 \mathrm{~kg}$ $P$ ha $^{-1}$. This could be due to the fact that soils low in $P$ will adsorb large amounts of $P$ leaving less for plants. On the other hand, when $P$ was applied at the highest level, availability of $P$ was increased that helped maize to attain the maximum height. Higher $\mathrm{P}$ also encourages the formation of new cells, promotes plant vigor and root growth, hastens leaf development which helps in harvesting more solar energy and later utilization of nitrogen which can contribute to the greater plant height. These findings are in agreement with those of Sahoo and Panda (2001) who reported that plant height in maize increased with increases in $\mathrm{P}$ levels. The highest increase of $37 \%$ in plant height was noted in the treatment that received SSP as a source of fertilizer in sorghum (Sharif et al 2014). These results are in line with the finding of Turk et al (2002) who found that plant height was enhanced with the application of P. Khalil et al (1988) and Khan et al (2014) reported that $N$ and $P$ alone or in combination increased plant height. The positive effect of the high $\mathrm{P}$ level on plant height was probably due to better development of the root system and nutrient absorption (Hussain et al 2006). A significant effect of $P$ application was observed on plant height by Stewart et al (2005), Ayub et al (2002), Maqsood et al (2001) and Khan et al (1999). Opala et al (2009) reported that the integrated application of organic and inorganic $\mathrm{P}$ sources had a significant positive role in the growth characteristics of maize.

The growth parameters (plant height, leaf area per plant and leaf area index) were also improved in plots with (+) PSB compared to without (-) PSB. According to Vyas and Gulati (2009), application of PSB improves soil fertility by releasing bound $\mathrm{P}$ and therefore improves crop growth and increases crop productivity. Plant 
growth promoting rhizobacteria produce plant growth promoting hormones and increase the root's absorbency causing an improvement in plant growth (Soleymanifard et al 2013). Amanullah and Khalid (2015), Hussain et al (2013), Chaturvedi (2006) and Dubey (1997) reported that the application of PSB increased plant height as compared to plots having no PSB. The inoculation with microorganisms having phosphate solubilizing ability concurrently improved plant $P$ uptake and crop growth. This increase in growth may be attributed to auxin production, ACC-deaminase activity production of organic acids or phosphatases to solubilize/mineralize $P$, thereby increasing phosphate nutrition of inoculated plants Fankem et al (2008), Naik et al (2008), Zafarul-Hye et al (2007), Gyaneshwar et al (2002), Abd- Alla (1994) and Chabot et al (1996). Strains of Pseudomonas tolaasii have been reported as bacteria with biocontrol activity and plant growth promotion in rice (Adhikari et al 2001) and also with the ability to enhance the growth and yield of canola (Dell'Amico et al 2008).

Leaf area is the most important photosynthesis acceptor and results in the higher assimilation of photosynthetic products. The functional leaf area of the crop canopy standing on the ground is the best parameter of crop productivity and a reference tool for crop growth. Our results indicated that PR significantly affected leaf area and LAI. LA and LAI improved with the application of faba bean residues as compared to the application of garlic and paper mulberry residues. This might be due to the supply of nutrients from the decomposition of the crop residues that helped supply the plants with an ample supply of nutrients and improved growth and development. Silva et al (2006) and Bakhsh et al (1999) reported that residue incorporation produced a higher number of leaves per plant and improved the leaf area.

The phosphorus source significantly affected the LA and LAI of maize. LA and LAI was improved with the higher $P$ level $\left(120 \mathrm{~kg} \mathrm{ha}^{-1}\right)$, while reduced LA and LAI was obtained with the application of the lower $P$ level $\left(60 \mathrm{~kg} \mathrm{ha}^{-1}\right)$ from each source either from the inorganic source (SSP) or the organic source (poultry manure). The increase in LA per plant and LAI at the higher $\mathrm{P}$ level might be due to the increase in the $P$ availability for the maize plants with positive impacts on plant growth which resulted in an increase in the number of leaves and LA per plant. Phosphorous also encourages the formation of new cells, promotes plant vigor and root growth, hastens leaf development and later utilization of nitrogen which can result in the greater LA. The increase in P solubility due to the PSB addition is of advantage in alkaline and calcareous soils. PSB is likely to prevent $P$ fixation by calcium, thus increasing $P$ availability for the crop. Chaturvedi (2006) reported that inorganic $P$ positively increased root growth resulting in the more nutrients and water uptake by the plant cells, leading to maximum LA and productivity of the crop. Balochgharayi (2011) and Aziz et al (2010) found P application significantly improved the LA per plant and LAI in maize. Amanullah et al (2009) reported that mean LA per plant in maize increased with the application of $P$ as compared to the control, and that the improvement in LA was more with SSP (single super phosphate) as compared to DAP (diammonium phosphate) and NP (nitrophos). Pirdashti et al (2010) concluded that the combined use of (50:50) inorganic $P$ fertilizer and an organic source expressively improved plant stature, LA per plant and chlorophyll content of soybean. Response of growth parameters indicates that poultry manure or inorganic $P$ source application can be used with a significant difference in plant growth and $P$ has a direct effect on leaf emergence, growth, and development of maize (Zafar et al 2013). 
The LA and LAI were also improved under plots with (+) PSB compared to without (-) PSB. According to Vyas and Gulati (2009), the application of phosphate solubilizing microorganisms improved soil fertility by releasing bound $P$ and therefore improved crop growth and increased crop productivity. Increased plant growth (LA) and nutrient uptake as a consequence of inoculation of PSB under field conditions were also reported in wheat (Selvakumar et al 2011, 2009), maize (Hameeda et al 2008, Kumar et al 2007), rice (Sharma et al 2014, Ashrafuzzaman et al 2009) and chickpea (Rudresh et al 2005). There is currently a considerable interest in the species of the genus Pseudomonas (PSB), which are being exploited for better crop production due to their rapid colonization and production of growthpromoting substances (Selvakumar et al 2009, Shaharooma et al 2008, Kumar et al 2007). Kupulnik et al (1982) demonstrated that maize seed inoculated with Azospirillum caused an increase in leaf numbers and finally some increase in yield as compared to no treatment. Chaturvedi (2006) revealed that LA and LAl increased with the application of PSB. Application of PSB in combined treatment with DAP and SSP with poultry manure significantly increased the LA as compared to their sole application (Zafar et al 2011). Amanullah and Khalid (2015) and Amanullah and Khan (2015) reported that application of $P$ along with PSB improved LA and LAI in maize.

Yield is an important measure in evaluating the adaptability of a crop to the ecological disparity (Seleiman et al 2011). Yield parameters are the end product of management strategies and considered to be vital parameters. Total dry-biomass yield $\left(\mathrm{kg} \mathrm{ha}^{-1}\right)$ was significantly affected by PR, PS and PSB. Application of faba bean residue increased biomass yield of the maize hybrid as compared to garlic and paper mulberry residues. This might be due to the supply of nutrients from the decomposition of residues that helped the ample supply of nutrients for the plants and improved the growth, development and ultimately the yield. Arif et al (2011) and Shafi et al (2007) reported that higher dry-biomass yields were recorded for the plots of maize having the residues incorporated compared with the residues removed. Incorporation of residues and their subsequent decomposition in soil might release plant nutrients slowly throughout the crop growth period, leading to better uptake of nutrients and higher yields in both rice and vegetables (Rajput and Warsi 1991).

The biomass of the maize hybrid was improved with $\mathrm{P}$ application at the highest levels $\left(120 \mathrm{~kg} \mathrm{ha}^{-1}\right)$ compared to the lower $\mathrm{P}$ level $\left(60 \mathrm{~kg} \mathrm{ha}^{-1}\right)$. This result may also be due the increased availability of $P$ which, augmented with increased growth and development, produced maximum yield. Amanullah and Khalid (2015) revealed that improvement in biomass yield and the healthier growth and development of the plants was due to optimum and better availability of plant nutrients. This was related to better root growth allowing plants to take up more nutrients from the soil as well as moisture during the growing period. Masood et al (2011) reported that the root growth of corn plants was optimum at $100 \mathrm{~kg} \mathrm{ha}^{-1} \mathrm{P}$ level which resulted in the higher biomass yield due to effective photosynthesis and other plant physiological activities at the higher $P$ level. These results are in accordance with those of Hameeda et al (2006), Singaram and Kothandaraman (1994) who reported that stover and biomass yield was highest with the highest $P$ level. The increase in crop growth rate and LAI with P application (Amanullah et al 2010a), may have resulted in higher biomass in maize. Intensification in yield and yield components of summer 
maize, due to fertilizer management under semiarid climates, was earlier reported by lqbal et al (2015), Khan et al (2013), Zafar et al (2011) and Cheema et al (2010). The increase in yield might be due to the combined application of $P$ and compost (Biswas 2011). Amanullah and Khalid (2015) and Amanullah and Khan (2015) reported that the plots inoculated with PSB (+) along with phosphorus fertilization produced the highest biomass.

\section{CONCLUSION}

The results showed that inorganic-P from source (SSP) was found to be better than organic- $P$ (poultry manure) in terms of better growth and biomass yield of the selected hybrid maize crop. However, the higher rate of $P\left(120 \mathrm{~kg} \mathrm{ha}^{-1}\right)$ from the organic source (poultry manure) was far better than the lower rate of $P\left(60 \mathrm{~kg} \mathrm{ha}^{-1}\right)$ from SSP. The combined application of $P$ at $120 \mathrm{~kg} \mathrm{ha}^{-1}$ either from the organic source (poultry manure) or inorganic source (SSP) along with faba bean residues and inoculation of the seed with phosphate solubilizing bacteria (PSB) enhanced phenological development, improved growth and biomass yield of hybrid maize under a semiarid climate. Application of higher $P$ rate $\left(120 \mathrm{~kg} \mathrm{ha}^{-1}\right)$ either from organic or inorganic source along with seed inoculation (+PSB) and legume residues could enhance phenology, improve growth and biomass yield of the hybrid maize in the study area. Further research is needed to study if the residual effect of poultry manure may be more long-lasting and economical than the residual effect of chemical P-fertilizer on the productivity of the subsequent crops.

\section{ACKNOWLEDGMENT}

We are thankful to the Department of Agronomy, The University of Agriculture Peshawar, Pakistan for the technical help and encouraging us to conduct and complete this research work.

\section{REFERENCES}

Amanullah and Khan A. 2015. Phosphorus and compost management influence maize (Zea mays L.) productivity under semiarid condition with and without phosphate solubilizing bacteria. Frontiers in Plant Science 6:1-8

Amanullah and Khalid S. 2015. Phenology, growth and biomass yield response of maize (Zea mays L.) to integrated use of animal manures and phosphorus application with and without phosphate solubilizing bacteria. Journal of Microbial and Biochemical Technology 7:439-444

Amanullah A, Zahid A, Iqbal \& Ikramullah. 2016. Phosphorus and tillage management for maize under irrigated and dryland conditions. Annals of Plant Sciences 5(3):1304-1311

Amanullah, Asif M \& Nawab K. 2010. Impacts of planting density and P-fertilizer source on the growth analysis of maize. Pakistan Journal of Botany 42(4):23492357

Amanullah, Asif M, Malhi SS \& Khattak RA. 2009. Effects of P-fertilizer source and plant density on growth and yield of maize in northwestern Pakistan. Journal of Plant Nutrient 32(10-12):2080-2093 
Amujoyegbe BA, Opabode JT \& Olayinka A. 2007. Effect of organic and inorganic fertilizer on yield and chlorophyll content of maize (Zea mays $L$ ) and Sorghum (Sorghum bicolour L Moench). African Journal of Biotechnology 6(16):18691873

Arif M, Jan MT, Khan MJ, Saeed M, Munir I, Ziauddin, Akbar H, Shah S \& Khan MZ. 2011. Effect of cropping system and residue management on maize. Pakistan Journal of Botany 43(2):915-920

Arya KC and Singh SN. 2001. Productivity of maize as influenced by different levels of phosphorus, zinc and irrigation. The Indian Journal of Agricultural Sciences 71:57-59

Ashrafuzzaman M, Hossen FA, Ismail MR, Hoque MA, Islam MZ, Shahidullah SM \& Meon S. 2009. Efficiency of plant growth-promoting rhizobacteria (PGPR) for the enhancement of rice growth. African Journal of Biotechnology 8(7):12471252

Ayub M, Nadeem MA, Sharar MS \& Mahmood N. 2002. Response of maize (Zea mays L.) fodder to different levels of nitrogen and phosphorus. Asian Journal Plant Sciences 1(4):352-354

Aziz T, Ullah S, Sattar A, Nasim M \& Farooq. 2010. Nutrient availability and maize (Zea mays L.) growth in soil amended with organic manures. International Journal of Agriculture and Biology 12(4):621-624

Bakhsh A, Gurmani AH, Bhatti AU \& Rehman H. 1999. Effect of balanced application of N, P and K on the grain yield of wheat. Sarhad Journal of Agriculture 15(4):453457

Biswas DR. 2011. Nutrient recycling potential of rock phosphate and waste mica enriched compost on crop productivity and changes in soil fertility under potato-soybean cropping sequence in an inceptisol of indo-gangetic plains of india. Nutrient Cycling Agroecosystems 89(1):15-30

Chaturvedi I. 2006. Effects of phosphorus levels alone or in combination with phosphate-solubilizing bacteria and farmyard manure on growth, yield and nutrient up-take of wheat (Triticum aestivum). Journal of Agriculture and Social Sciences 2(2):96-100

Cheema MA, Farhad W, Saleem MF, Khan HZ, Munir A \& Wahid MA. 2010. Nitrogen management strategies for sustainable maize production. Crop and Environment $1(1): 49-52$

Dubey SK. 1997. Co-inoculation of phosphorus solubilizing bacteria with Bradyrhizobium japonicum to increase phosphate availability to rainfed soybean on vertisol. Journal of the Indian Society of Soil Science 45(3):506-509

El-Yazeid AA, Abou-Aly HA, Mady MA \& Moussa SAM. 2007. Enhancing growth, productivity and quality of squash plants using phosphate dissolving microorganisms (bio phosphor) combined with boron foliar spray. Research Journal of Agriculture and Biological Sciences 3(4):274-286

Hafeez FY, Hameed S, Zaidi AH \& Malik KA. 2002. Bio-fertilizers for Sustainable Agriculture. In Azam F, Iqbal MM, Inayatullah C \& Malik KA (eds) Techniques for Sustainable Agriculture (pp67-73). Nuclear Institute of Agriculture and Biology, Faisalabad, Pakistan

Hamdi EL and Woodard HJ. 2004. Response of early corn growth to fertilizer phosphorus rates and placement methods. Journal of Plant Nutrition 18(6):1103-1120

Hameeda B, Harini G, Rupela OP, Wani SP \& Reddy G. 2008. Growth promotion of 
maize by phosphate-solubilizing bacteria isolated from composts and macrofauna. Microbiological Research 163(2):234-242

Hameeda B, Rupela OP, Reddy G \& Satyavani K. 2006. Application of plant growthpromoting bacteria associated with composts and macro fauna for growth promotion of pearl millet (Pennisetum glaucum L.). Biology and Fertility of Soils 43:221-227

Han W and He M. 2010. The application of exogenous cellulase to improve soil fertility and plant growth due to acceleration of straw decomposition. Bioresource Technology 101(10):3724-3731

Hussain N, Khan AZ, Akbar H \& Akhtar S. 2006. Growth factors and yield of maize as influenced by phosphorus and potash fertilization. Sarhad Journal of Agriculture 22(4):579-583

Hussain N, Khan MB \& Ahmad R. 2008. Influence of phosphorus application and sowing time on Performance of wheat in calcareous soils. International Journal of Agriculture and Biology 10(4):399-404

Iqbal A, Amanullah \& Iqbal M. 2015. Impact of potassium rates and their application time on dry matter partitioning, biomass and harvest index of maize (Zea mays) with and without cattle dung application. Emirates Journal of Food and Agriculture 27:447-453

Khan F, Khan S, Fahad S, Faisal S, Hussain S, Ali S \& Ali A. 2014. Effect of different levels of nitrogen and phosphorus on the phenology and yield of maize varieties. American Journal of Plant Sciences 5(5):2582-2590

Khan HZ, Nadeem M, Iqbal S, Akbar N \& Iqbal A. 2013. Response of spring maize (Zea mays L.) to integrated nitrogen management. Crop and Environment 4(1):6-10

Khan MA, Khan MU, Ahmad K \& Sadiq M. 1999. Yield of maize hybrid-3335 as affected by NP levels. Pakistan Journal of Biological Sciences 2(3):857-859

Khan MB, Hussain N \& Ahmad R. 2008. Influence of phosphorus application and sowing time on performance of wheat in calcareous soils. International Journal of Agriculture and Biology 10(4):399-404

Khan MS, Zaidi A, Ahemad M, Oves M \& Wani PA. 2010. Plant growth promotion by phosphate solubilizing fungi current perspective. Archives of Agronomy and Soil Science 56(1):73-98

Kumar B, Trivedi P \& Pandey A. 2007. Pseudomonas corrugata: A suitable bacterial inoculant for maize grown under rainfed conditions of Himalayan region. Soil Biology and Biochemistry 39(12):3093-3100

Kumar K and Goh KM. 2002. Management practices of antecedent leguminous and non-leguminous crop residences in relation to winter wheat yield, nitrogen uptake, soil nitrogen mineralization and simple nitrogen balance. European Journal of Agronomy 16(4):295-308

Kupulnik Y, Sarig S, Nur A, Okan Y \& Henis Y. 1982. Effect of Azospirillum inoculation on growth and yield maize. Israel Journal of Botany 31(1-4):247-255

Li S, Lia Y, Lia X, Tiana X, Zhaoa A, Wanga S, Wanga S \& Shia J. 2015. Effect of straw management on carbon sequestration and grain production in a maize-wheat cropping system in Anthrosol of the Guanzhong plain. Soil and Tillage Research 157:43-51

Maliha R, Samina K, Najma A, Sadia A \& Farooq L. 2004. Organic acids production and phosphate solubilization by phosphate solubilizing microorganisms under in vitro conditions. Pakistan Journal of Biological Sciences 7(2):187-196

Masood T, Gul R, Munsif F, Jalal F, Hussain Z, Noreen N, Khan H, Nasiruddin \& Khan 
H. 2011. Effect of different phosphorus levels on the yield and yield components of maize. Sarhad Journal of Agriculture 27(2):167-170

Ministry of National Food Security \& Research (MNFSR). 2013. Agricultural statistics of Pakistan. Government of Pakistan. Minstery of National Food Security and Research. Division (Economic wing) Islamabad

Naik PR, Raman G, Narayanan KB \& Sakthivel N. 2008. Assessment of genetic and functional diversity of phosphate solubilizing fluorescent $P$ seudomonads strain from rhizospheric soil. BMC Microbiology 8:230

Nezarat S and Gholami A. 2009. Screening plant growth promoting rhizobacteria for improving seed germination, seedling growth and yield of maize. Pakistan Journal of Biological Sciences 12(1):26-32

Pirdashti H, Motaghian A \& Bahmanyar MA. 2010. Effect of organic amendments application on grain yield, leaf chlorophyll content and some morphological characteristics in soybean cultivars. Journal of Plant Nutrition 33(4):485-495

Qhorchiany M, Akbari GH, Alikhani H, Allahdadi A \& Zarei M. 2011. Effects of mycorrhizal fungi and bacteria, Pseudomonas fluorescence Rbskvlar ear characteristics, chlorophyll content and yield of corn in drought conditions. Journal of Soil and Water 21(1):97-114

Rajput AL and Warsi AS. 1991. Contribution of organic materials to nitrogen economy to rice production. Indian Journal of Agronomy 36(3):455-456

Rengel $Z$ and Marschner P. 2005. Nutrient availability and management in the rhizosphere: exploiting genotypic differences. The New Phytologist 168:305312

Rudresh DL, Shivaprakash MK \& Prasad RD. 2005. Effect of combined application of rhizobium, phosphate-solubilizing bacterium and Trichoderma spp. on growth, nutrient uptake and yield of chickpea (Cicer arietinum L.). Applied Soil Ecology 28(2):139-146

Sahoo SC and Panda M. 2001. Effect of phosphorus and de-tasseling on yield of baby-corn. Indian Journal of Agricultural Sciences 71(1):21-22

Seleiman, Mahmoud M, Aal ISA \& Zahran G. 2011. Effect of sowing dates on productivity, technological and rheological characteristics of bread wheat. Journal of Agro Crop Sciences 2(1):1-6

Selvakumar G, Joshi P, Suya LP, Mishra PK, Joshi GK, Bisht JK, Bhatt JC \& Gupta HS. 2011. Pseudomonas lurida M2RH3 (MTCC9245), a psychrotolerant bacterium from the Uttarakhand Himalayas, solubilizes phosphate and promotes wheat seedling growth. World Journal of Microbiology and Biotechnology 27(5):11291135

Selvakumar G, Joshi P, Nazim S, Mishra PK, Bisht JK \& Gupta HS. 2009. Phosphate solubilization and growth promotion by Pseudomonas fragi CS11RH1 (MTCC 8984) a psychrotolerant bacterium isolated from a high altitude Himalayan rhizosphere. Biologia 64(2):239-245

Shafi M, Bakht J, Jan MT \& Shah Z. 2007. Soil C and N dynamics and maize (Zea may L.) yield as affected by cropping systems and residue management in NorthWestern Pakistan. Soil \& Tillage Research 94(2):520-529

Shahzad MA, Din WU, Sahi ST, Khan MM, Ehsanullah \& Ahmad M. 2007. Effect of sowing dates and seed treatment on grain yield and quality of wheat. Pakistan Journal of Agricultural Sciences 44(4):581-583

Sharif M, Arif M, Burni T, Khan F, Jan B \& Khan I. 2014. Growth and phosphorus uptake of sorghum plants in salt affected soil as affected by organic materials 
composted with rock phosphate. Pakistan Journal of Botany 46(1):173-180

Sharma A, Shankhdhar D, Sharma A \& Shankhdhar SC. 2014. Growth promotion of the rice genotypes by pgprs isolated from rice rhizosphere. Journal of Soil Science and Plant Nutrition 14(2):505-517

Singaram P and Kothandaraman GV. 1994. Studies on residual, direct and cumulative effect of phosphorus sources on the availability, content and uptake of phosphorus and yield of maize. Madras Agriculture Journal 81(8):425-429

Soleymanifard A, Piri I \& Naseri R. 2013. The effect of plant growth promoting bacteria on physiological and phenological traits of maize (Zea mays L.) at different levels of nitrogen fertilizer. Bulletin of Environment, Pharmacology and Life Sciences 2(9):55-64

Steel RGD and Terrie JH. 1996. Principles and procedures of statistics: a biometrical approach (2nd edn). McGraw-Hill, New York

Stefan T. 2003. Organic agriculture: sustainability market policies. CAB Organization for Economic Co-operation and Development

Stewart BW, Albrecht SL \& Skirvin KW. 2000. Crop residue position and interference with wheat seedling development. Soil and Tillage Research 55:175-182

Stewart WM, Dibb DW, Johnston AE \& Smyth TJ. 2005. The contribution of commercial fertilizer nutrients to food production. Agronomy Journal 97(1):1-6

Tambone F, Genevini P \& Adani F. 2007. The effects of short-term compost application on soil chemical properties and on nutritional status of maize plant. Compost Science and Utilization 15(3):176-183

Vyas $P$ and Gulati A. 2009. Organic acid production in vitro and plant growth promotion in maize under controlled environment by phosphate-solubilizing fluorescent Pseudomonas. BMC Microbiology 9(1):174

Weaterman $P$ and Bicudo J. 2014. Management considerations for organic waste use in agriculture. Bioresource Technology 96(6):215-221

Zafar M, Rahim N, Shaheen A, Khaliq A, Arjamand T, Jamil M, Rehman Z \& Sultan T. 2011. Effect of combining poultry manure, inorganic phosphorus fertilizers and phosphate solubilizing bacteria on growth, yield, protein content and $\mathrm{P}$ uptake in maize. Advances in Agriculture and Botanics 3(1):247-254

Zafar M, Abbasi MK \& Khaliq A. 2013. Effect of different phosphorus sources on the growth, yield, energy content and phosphorus utilization efficiency in maize at Rawalakot Azad Jammu and Kashmir, Pakistan. Journal of Plant Nutrition 36(12):1915-1934

Zafar-ul-Hye M, Zahir ZA, Shahzad SM, Naveed M, Arshad M \& Khalid M. 2007. Preliminary screening of rhizobacteria containing ACC deaminase for promoting growth of lentil seedlings under axenic condition. Pakistan Journal of Botany 39(5):1725-1738 